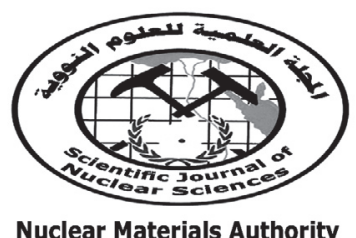

ISSN 2314-5609

Nuclear Sciences Scientific Journal vol. 1, p 57-68

2012

P.O.Box 530 Maadi, Cairo, Egypt

\title{
MINERALOGY AND RADIOACTIVITY OF SOME PEGMATITE BODIES, SOUTHEASTERN SINAI, EGYPT
}

\author{
HESHAM A. EL NAHAS \\ Nuclear Materials Authority, Cairo, Egypt. B.O., 530 El Maadi
}

\begin{abstract}
The area under consideration constitutes the extreme eastern part of the Kid metamorphic belt in Sinai Peninsula. The Neoproterozoic rock units exposed there comprise gneisses, migmatites, old granitoids and monzogranites. Most of the pegmatite bodies encountered in the monzogranite rocks occur as plug-like bodies and veins of variable dimensions. These studied pegmatites are mainly of the simple unzoned type. They are composed of intergrowths of smoky quartz and pink K-feldspar with some accumulations of micas which host most of radioactive mineralizations. Radiomertrically, the concentration of eU ranges between 41 and $117 \mathrm{ppm}$ with an average of $73 \mathrm{ppm}$, while eTh varies between 160 and $433 \mathrm{ppm}$ with an average of $223 \mathrm{ppm}$. The Ra content reaches up to $94 \mathrm{ppm}$ with an average of $62 \mathrm{ppm}$. The radioelements variation diagrams illustrate that the distribution of radioelements is due to both magmatic origin and hydrothermal redistribution. The high level of radioactivity in the studied granitic pegmatites is mainly resulted from the presence of ishikawaite, thorite, uranothorite, thorianite, zircon, betafite and fluorite. Most of the studied radioactive minerals commonly occur in the metamict state. Other accessory minerals like anatase, hematite and magnetite are also recorded. The study reports for the first time the presence of Ishikawaite-Th, where Th prevails U. Ishikawaite-Th grains contain exsolution intergrowths of ishikawaite-U and thorianite.
\end{abstract}

\section{INTRODUCTION}

Post-collision alkaline magmatism ( 610 $580 \mathrm{Ma})$ is widely distributed in the northern part of the Neoproterozoic Arabian-Nubian Shield (ANS), i.e. the northern part of the Egyptian Eastern Desert and Sinai. The basement rocks of southern Sinai were recently studied in detail by many authors (eg. El Sayed 1993; El Mowafy 1994\&2003; Hamd 1995; El Metwally, 1993; Moghazy et al., 1998; El Aassy et al. 1999, Abu El-Enen, 2008, El Baily and Streck, 2009...etc). The present study throw light on the radioactivity and mineral constituents of some mineralized pegmatite bodies, existing in the study area.

\section{GEOLOGIC SETUP}

The area under investigation occupies the extremely eastern part of the Kid metamorphic belt in Sinai Peninsula. It is bounded by lat. $28^{\circ} 15^{\prime}-28^{\circ} 25^{\prime} \mathrm{N}$ and long. $34^{\circ} 05^{\prime}-34^{\circ} 15^{\prime} \mathrm{E}$, and covers an area of about $90 \mathrm{~km}^{2}$ covered by crystalline igneous, metamorphic rock units and quaternary alluvial sediments. These rock units comprise gneisses and migmatites, old granitoids and monzogranites (Fig. 1). These rocks are dissected by several wadies; Wadi Majirat, Wadi Marwa, Wadi Candali and Wadi Yethmid in addition to their tributaries filled with alluvial sediments. 


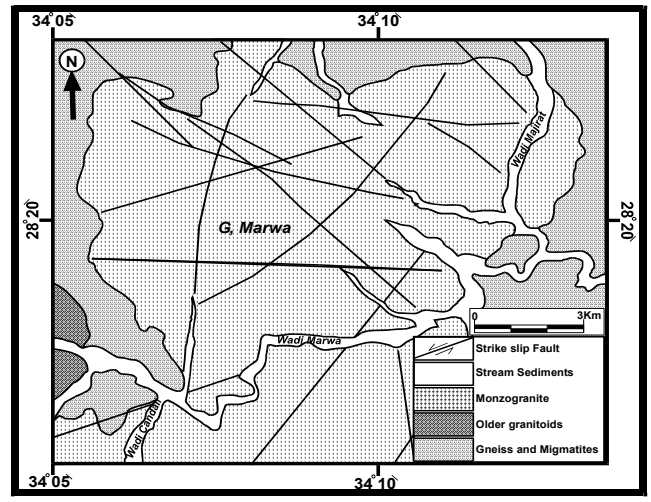

Fig. 1: Geologic map of the study area

Gneisses and migmatites represent the rocks mainly surrounding the monzogranites from north, east and west. These rocks are intruded by old granitoids and monzogranites with sharp contacts (Fig. 2a). They form moderate to low relief and characterized by the foliation and gneissose structures with alternation of melanocratic and leucocratic bands. They are composed mainly of biotite-hornblende and quartz-feldspar rich bands respectively. The old granitoids crop out at Wadi Yethmid to the extreme west of the study area. They are hard, massive, medium to coarse-grained and grey to yellowish grey in color forming moderate to low relief. These old granitoids in the area vary in their composition from tonalite to granodiorite and composed essentially of plagioclase, quartz, K-feldspar, biotite and hornblende.

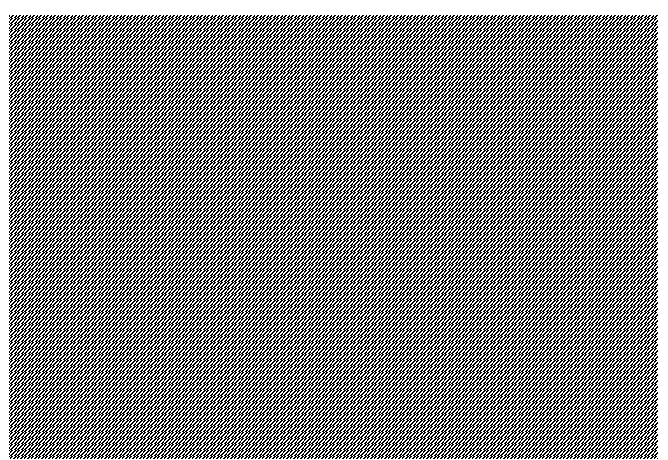

Fig. 2a: Sharp contact between gneisses (Gn) and monzogranites (MG)
Monzogranites, of high to moderate relief, are the main rock unit and occupy the central part of the study area. The monzogranites are characterized by red to pink color, medium to coarse-grained and sharp contacts with the adjacent rock units. Apophyses and off shoots commonly extend from monzogranites to the country rocks (El Feky et al., 2011). Monzogranites of G. Marwa are extensively fractured and jointed. They are invaded by pegmatite bodies and veins. Pegmatites encountered in the study area mostly occur as small veins, pockets and pod-like bodies of variable dimensions in monzogranites. Salterly (1957) divided the pegmatites into simple and complex. Most of the pegmatite bodies in the study area are of the simple zoned type of Salterly (1957) composed of intergrowths of smoky quartz and pink K-feldspar with some accumulations of micas in which most of radioactive mineralizations are present (Fig. 2b). Texturally, pegmatites are distinguished by large size crystals compared to the normal grain size of the hosting monzogranites.

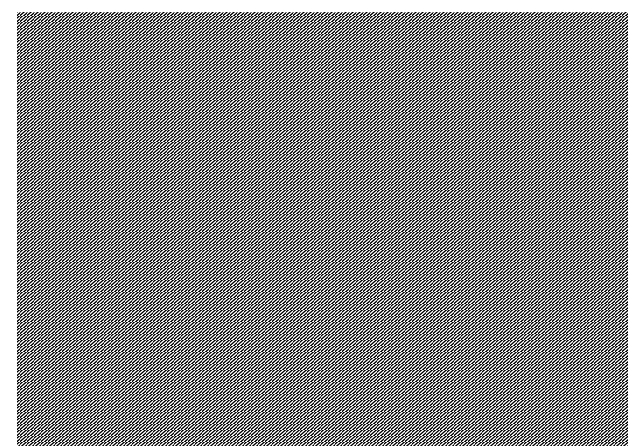

Fig. 2b: pegmatite pocket intruded in the monzogranites of G. Marwa

\section{SAMPLING AND TECHNIQUES}

A total of eleven samples were collected from different pegmatite bodies encountered in monzogranites around the different wadies for radiometric and mineralogical studies. These samples were subjected to comminution processes through a laboratory jaw crusher and roll mill to liberate the considered 
radioactive minerals from the other gangue ones. Quantitative determination of the radioactive elements; eU, eTh, $\mathrm{Ra}(\mathrm{eU})$ and $\mathrm{K}$ was obtained using the multi-channel analyzer of $\gamma$-ray spectrometer, (NaI "T1"-detector). The system of $\gamma$-ray spectrometry consists of bicorn scintillation detector, $\mathrm{NaI}$ "T1" crystal $76 \times 76 \mathrm{~mm}$, hermitically sealed with a photomultiplier tube in aluminum housing. A proper weight (300-350 gm) of the crushed sample was placed in a standard size plastic container, sealed well and left for at least 30 days to accumulate free radon and to attain radioactive equilibrium.

Because of these radioactive minerals mainly occur in the medium to very fine sized fractions, the samples were sieved by using $1 \mathrm{~mm}$ and $0.053 \mathrm{~mm}$ sieves. The in-between fractions $(1-0.053 \mathrm{~mm})$ were subjected to the heavy liquid separation using bromoform solution (sp. gr. $2.81 \mathrm{~g} / \mathrm{cm}^{3}$ ) and methylene iodide solution (di-iodomethane with $\mathrm{sp} . \mathrm{gr} .=3.31 \mathrm{~g} / \mathrm{cm}^{3}$ ). The obtained heavy fractions were magnetically classified according to the magnetic susceptibility of the heavy minerals. Magnetite was removed using a permanent hand magnet. The free-magnetite heavy minerals fractions were fractionated using the High Intensity Frantz Isodynamic Magnetic Separator (model L-1). These magnetic fractions were examined carefully by the binocular stereomicroscope, X-ray Diffraction (XRD) technique using Philips Xray diffractometer (Model PW- 1050/80) and Environmental Scanning Electron Microscope (ESEM) using Philips Model XL 30 supported by an energy dispersive X-ray unit (EDX).

\section{PETROGRAPHIC CHARACTERISTICS}

Monzogranites in the study area are generally massive, medium to coarse-grained and characterized by their greyish pink color. They are composed essentially of plagioclase, quartz, potash feldspar, with minor mafic minerals exhibiting hypidiomorphic texture. Zircon, allanite, sphene and opaques are the main accessory minerals, while the secondary minerals include chlorite, sericite and kaolin.
Plagioclase $\left(\mathrm{An}_{15-23}\right)$ forms anhedral to subhedral grains and shows zoning and lamellar twinning (Fig.3a). Potash feldspar forms subhedral to anhedral prismatic crystals of string and patchy perthitic texture. Sometimes, the minerals of the perthitic texture show partial alteration to sericite. Quartz occurs as anhedral coarse grained crystals. Some quartz minute crystals are occupying the reaction boundaries between perthite crystals. Mafic minerals are mainly biotite and hornblende. Biotite occurs as subhedral to anhedral irregular flakes, strongly pleochroic from yellowish brown to dark brown. Some biotite crystals are partially altered to chlorite and iron oxide (Fig.3b). Hornblende occur as subhedral elongated crystals and characterized by strong pleochroism from brownish green to green color. Zircon is present as randomly distributed fine to very fine-grained euhedral crystals commonly associated with biotite and rarely in plagioclase and quartz. Allanite occurs as fine euhedral to subhedral crystals and characterized by zonation (Fig. 3c). Sphene is present as prismatic, rhombic and sometimes anhedral crystals (Fig. 3d).

The studied pegmatites are massive, coarse to very coarse-grained and buff in color. Petrographically, they consist of megacrysts of potash feldspar, quartz, plagioclase in addition to biotite and muscovite. Potash feldspar occurs as subhedral to euhedral coarse grains and represented as perthitic texture and antiperthite crystals forming graphic texture with quartz and plagioclase. Most of quartz crystals occur as megacrysts graphically intergrown with both textures (Fig. 3e, f), while some of them are present as minute crystals between potash feldspar crystals. Plagioclase $\left(\mathrm{An}_{10-20}\right)$ ranges in composition from albite to oligoclase. It occurs as subhedral to anhedral crystals and characterized by lamellar twinning and sometimes corroded with potash feldspar and quartz (Fig. 3g). Biotite flakes are characterized by strong pleochroism from yellowish brown to dark brown color (Fig. 3h). Muscovite flakes are commonly associated with quartz and potash feldspar. 

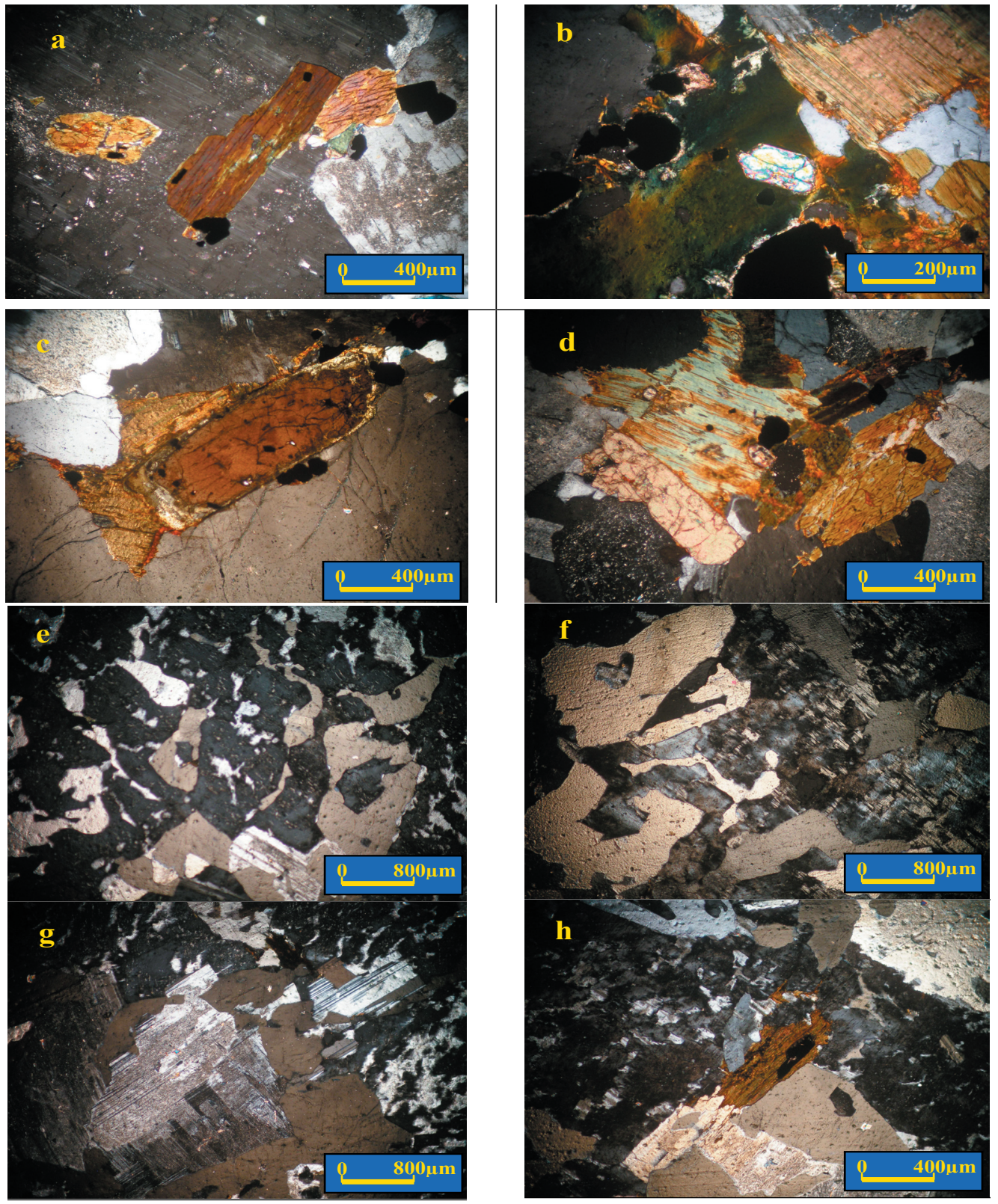

Fig.3: Photmicrographs of a)crystal of hornblende included within plagioclase, monzogranites, b)zircon, biotite and chlorite, monzogranites, c)zoned crystal of allanite associated with quartz and plagioclase, monzogranites, d)sphene with zircon in chloritized biotite and basal section of hornblende, monzogranite, e)megacryst of minerals in perthitic texture graphically intergrown quartz, pegmatite, f)megacryst of antiperthite graphically intergrown quartz, pegmatite, g)plagioclase associating quartz, pegmatite, and h)biotite associating antiperthite and quartz, pegmatite 


\section{MINERALOGY AND RADIOACTIVITY \\ RADIOACTIVITY}

The results of the radiometric measurements of eU, eTh, $\mathrm{Ra}(\mathrm{eU})$ and $\mathrm{K}$ for the studied pegmatite samples with the calculated ratios; eTh/eU and eU/Ra are listed in Table (1). The radiometrical element concentration of eU ranges between 41 and $117 \mathrm{ppm}$ with an average of $73 \mathrm{ppm}$, while eTh varies between 160 and $433 \mathrm{ppm}$ with an average of $223 \mathrm{ppm}$. The $\mathrm{Ra}(\mathrm{eU})$ content reaches up to $94 \mathrm{ppm}$ with an average of $62 \mathrm{ppm}$. Most of the studied samples exhibit low concentrations of $\mathrm{K}$, $\left(\mathrm{P}_{9} 11\right)$. This may be attributed to the post magmatic processes that affected the studied rocks as koalinization. The results reflect the high concentrations of $\mathrm{Th}$ and $\mathrm{U}$ in the studied mineralized pegmatites due to the presence of the radioactive minerals as will be seen. Uraniferous granites and pegmatites are radiometrically characterized by high contents of $U$ ( $>8 \mathrm{ppm}$ ) and/or Th (>16 ppm) with or without U mineralization (Darnely, 1982). The studied pegmatites have higher values of eU and eTh than those recorded for the World uraniferous pegmatites $(\mathrm{av}=28$ and 21 for $\mathrm{U}$ and $\mathrm{Th}$ respectively, Ford, 1982). Also, these values are higher than those of the Egyptian uraniferous pegmatites(av. $=33$ and $28 \mathrm{ppm}$ for $\mathrm{U}$ and $\mathrm{Th}$ respectively, Moharam, 2004\&2006).

Table (1): Radioelements concentrations of eU, eTh, $\mathrm{Ra}(\mathrm{eU})$ and $\mathrm{K}$ and some ratios for the studied granitic pegmatites.

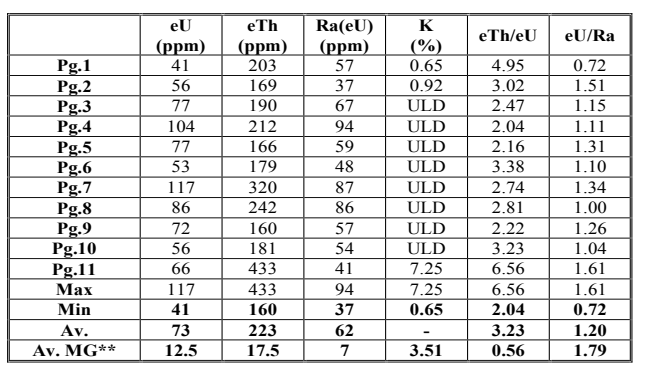

Av. $\mathrm{MG}=$ Average concentrations of the radioelements for the surrounding monzogranites of G. Marwa (El Feky, et al., 2011).ULD = under limit of detection

The average eU, eTh, Ra and $\mathrm{K}$ for the surrounding monzogranites is $13,18,7 \mathrm{ppm}$ and $3.51 \%$ respectively (El Feky et al., 2011). The studied pegmatites compared to these monzogranites have higher concentrations of these radioelements.
The average eTh/eU ratio of the pegmatite bodies is 3.23 , which is slightly less than the average continental crust value of approx. 3.8 (Van Schmus, 1995). Most of pegmatite samples have eU/Ra ratio more than unity (av.=1.2) reflecting a state of positive radioactive disequilibrium. This may be due to the scape of some Ra during the alkaline hydrothermal solutions. The eU-eTh variation diagram (Fig. 4a) for the studied pegmatites reflects positive correlation indicating that the magmatic processes played an important role in the concentration of radioelements. The figures show also that there is ill-defined relation between eTh/eU and eTh (Fig. 4b) and negative relation between $\mathrm{eTh} / \mathrm{eU}$ and $\mathrm{eU}$ (Fig. 4c), suggesting that the distribution of radioactive elements is due to magmatic processes as well as hydrothermal redistribution (Charbonneau, 1982).

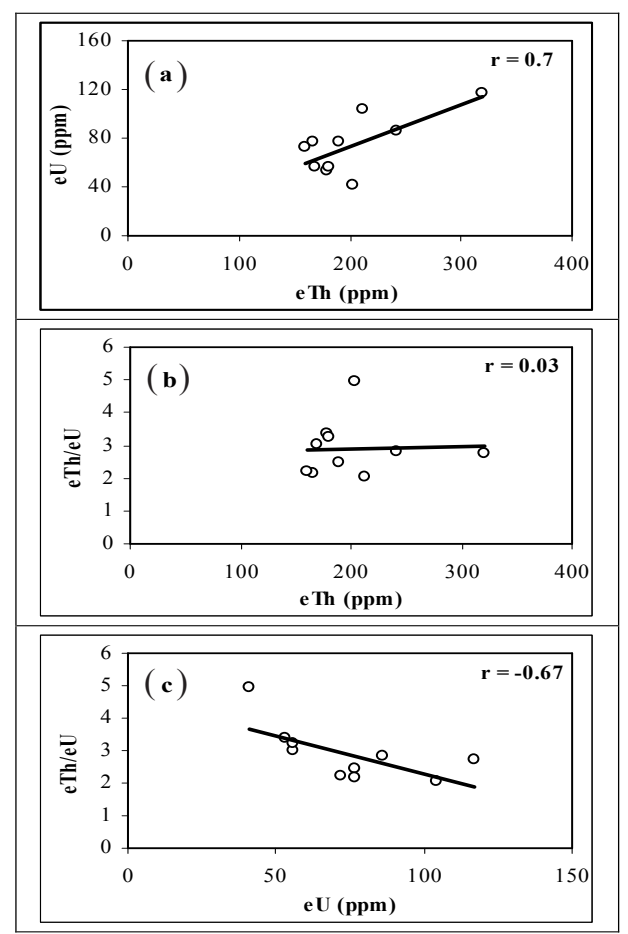

Fig. 4: Binary relationships showing a) eU versus eTh, b) eTh versus eTh/eU, and c) eU versus $\mathrm{eTh} / \mathrm{eU}$ 


\section{MINERALOGY}

In fact, most of the radioactive mineralizations of the studied pegmatites in the study area are associating the existing mica agglomerations. The most common radioactive and important minerals of the studied pegmatites are ishikawaite, thorite, uranothorite, thorianite, zircon, betafite and fluorite in addition to anatase, hematite and magnetite.

Ishikawaite: [(Th, U, Y,REE,Ca)(Nb,Ta,Ti) $\mathrm{O}_{4}$ : Ishikawaite is considered as uranium and thorium-rich samarskite mineral. Ishikawaite mostly occurs as medium to fine anhedral crystals, black to dark brown in color with vitreous luster and concoidal fractures (Fig. 5). The obtained data from ESEM analyses of the studied grains were plotted on the ternary diagram of Hanson et al., (1999), which shows that all points locate in ishikawaite field (Fig. 6) due to the dominant $U$ and $T h$. In fact, the ESEM analyses of ishikawaite mineral grains reveal that most of the analyzed grains show Th exceeds U (Fig. 7a\&c), whereas some grains are characterized by $\mathrm{U}$ exceeding $\mathrm{Th}$ (Fig. 7b). So, ishikawaite can be classified, in the term of abundance of $\mathrm{U}$ and Th, as ishikawaite-Th and ishikawaite-U. Some ishikawaite-Th grains contain unoriented lamellae of ishikawaite-U (Fig. 7c). Regarding to REE content, Hanson et al.,(1999) stated that, ishikawaite and calciosamarskite are (LREE) depleted and (HREE+Y) enriched. A picked sample of ishikawaite mineral grains was carried out for X-ray diffraction analysis.

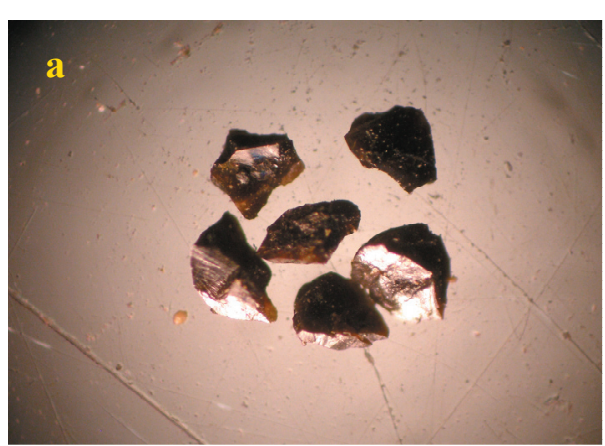

Fig. 5: Photomicrographs of the considered radioactive minerals; a) ishikawaite

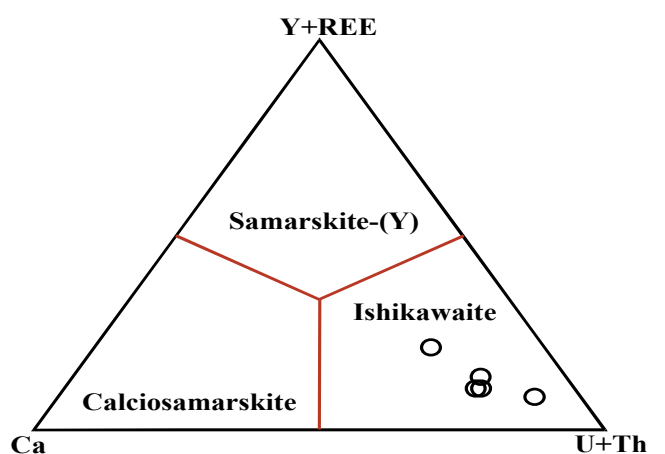

Fig. 6: Ternary diagram showing the A-site occupancy of samarskite-group minerals (after Hanson et al.,1999)
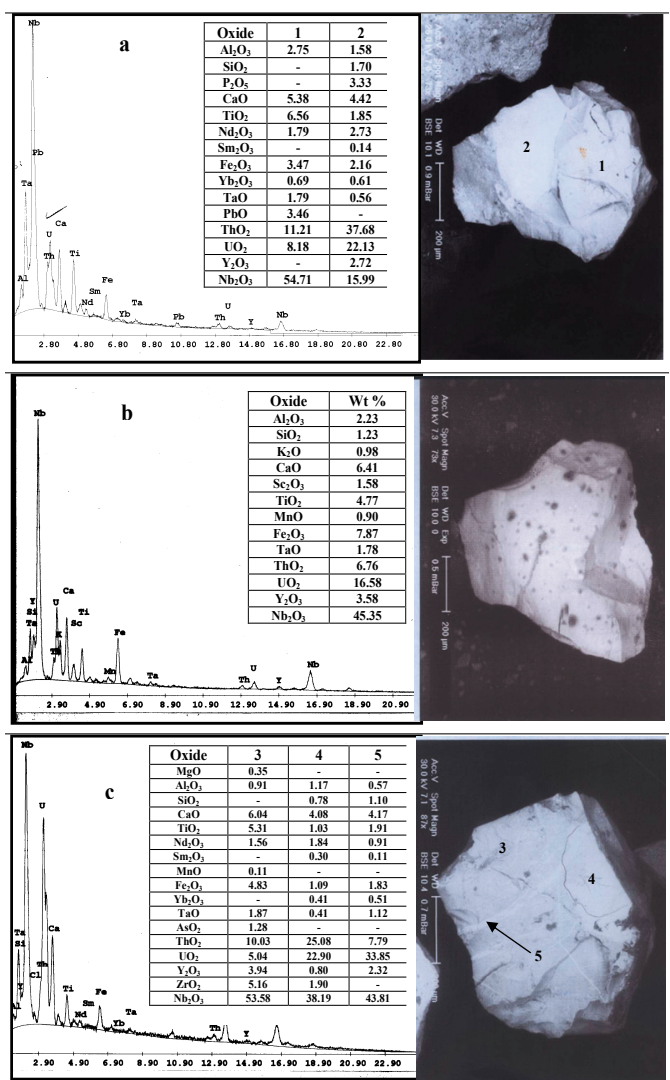

Fig. 7: EDX mineral analyses and backscattered ESEM image of [a] ishikawaite-Th grain (1) with inclusion of thorianite (2), [b] homogeneous ishikawaite-U grain, [c] ishikawaite-Th (3) with inclusion of thorianite (4) and unoriented lamellae of ishikawaite-U (5) 
The mineral grains are completely metamict, which was reflected by the amorphous $\mathrm{X}$-ray diffraction pattern, so the annealing to $1100^{\circ} \mathrm{C}$ for about six hours for X-ray diffraction analysis was necessary. The obtained $\mathrm{x}$ ray diffraction pattern of the annealed sample is plotted on Figure (6), illustrates that the mineral is wholly metamict and growing of the diffraction peaks of the mineral by annealing.

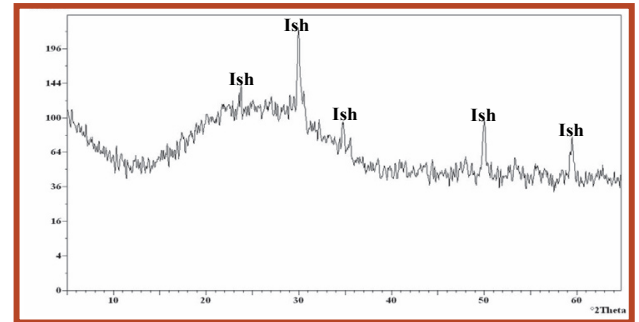

Fig. 8 : X-ray diffraction pattern of ishikawaite (ASTM card no. 2-590) after annealing

Thorite [ThSiO $]$ : Thorite occurs as anhedral to subhedral fine to very fine mineral grains that exhibit black to brownish black colors with metallic to submetallic luster (Fig. 9). The brownish tint of the studied grains may be due to the incrustation with iron oxides (El Nahas, 2006). Th and Si constitute the essential elements forming the mineral, while $\mathrm{Zr}$, $\mathrm{U}, \mathrm{Ca}, \mathrm{Fe}$ and $\mathrm{Al}$ are the elements existing in trace amounts (Fig. 10). Some thorite mineral grains contain appreciable amounts of more than $15 \% \mathrm{UO}_{2}$, so it can be referred as uranothorite (Fig. 10). The X-ray diffraction data are listed in Table (2).

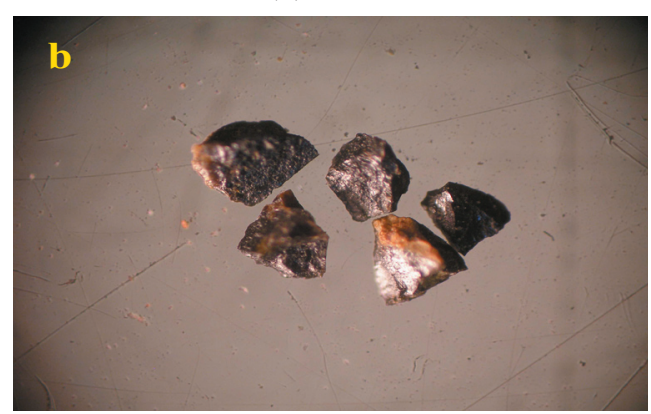

Fig. 9: Photomicrographs of the considered radioactive minerals; b) thorite

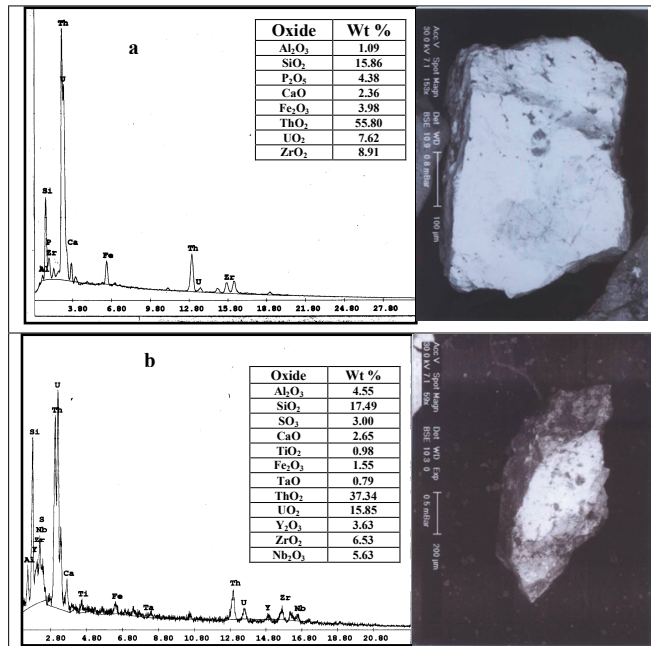

Fig. 10: EDX analyses and backscattered ESEM image of [a] thorite, [b] uranothorite

Table 2: X-ray diffraction data of zircon and thorite from the studied pegmatites

\begin{tabular}{||l|l|l|l|l|l||}
\hline $\begin{array}{c}\text { Measured } \\
\text { values }\end{array}$ & \multicolumn{2}{c|}{$\begin{array}{c}\text { Zircon } \\
(\mathbf{6 - 2 6 6 )}\end{array}$} & \multicolumn{2}{c|}{$\begin{array}{c}\text { Thorite } \\
(\mathbf{1 1 - 4 1 9 )}\end{array}$} \\
\hline $\mathbf{d A}^{\mathbf{0}}$ & $\mathbf{I}_{\mathbf{0}}$ & $\mathbf{d A}^{\mathbf{0}}$ & $\mathbf{I}_{\mathbf{0}}$ & $\mathbf{I}_{\mathbf{0}}$ & $\mathbf{d A}^{\mathbf{0}}$ \\
\hline 4.72 & 4 & & & 4.72 & 85 \\
\hline 4.44 & 32 & 4.43 & 45 & & \\
\hline 3.54 & 5 & & & 3.55 & 100 \\
\hline 3.31 & 100 & 3.30 & 100 & & \\
\hline 2.65 & 9 & 2.65 & 8 & 2.676 & 75 \\
\hline 2.52 & 44 & 2.518 & 45 & 2.516 & 30 \\
\hline 2.34 & 10 & 2.336 & 10 & 2.361 & 5 \\
\hline 2.22 & 8 & 2.217 & 8 & 2.222 & 30 \\
\hline 2.17 & 1 & & & & \\
\hline 2.07 & 18 & 2.066 & 20 & 2.019 & 20 \\
\hline 1.91 & 9 & 1.908 & 14 & & \\
\hline 1.83 & 3 & & & 1.834 & 65 \\
\hline 1.75 & 9 & 1.751 & 12 & 1.757 & 15 \\
\hline 1.71 & 33 & 1.712 & 12 & & \\
\hline 1.65 & 12 & 1.651 & 14 & 1.667 & 10 \\
\hline 1.55 & 2 & 1.547 & 4 & 1.578 & 10 \\
\hline 1.48 & 6 & 1.477 & 8 & 1.484 & 20 \\
\hline
\end{tabular}

Thorianite [(Th,U) $\left.\boldsymbol{O}_{2}\right]$ : The mineral is rarely observed in the studied mineralized pegmatite samples. It occurs as fine anhedral crystals of black colors and metallic to submetallic luster. Mostly, thorianite grains are associated as inclusions within ishikawaiteTh, as shown in backscattered ESEM image and analysis (Fig. 7a\&c). The mineral, also contains appreciable amount of $\mathrm{Nb}$ up to $34 \%$. It is worthy to point out that thorianite in the studied pegmatites may be formed as exsolution intergrowths in ishikawaite-Th mineral grains. 
Zircon [ZrSiO ]: Zircon is recently used as a guide for U mineralization (Dardier, 1999; Abdel Warith, 2001 and El Mansi et al., 2004). Zircon occurs as euhedral to subhedral yellowish grey to greenish grey, translucent to opaque mineral grains with resinous luster, which is referred as malacon zircon (Fig. 11). Decay of the radioactive elements in the zircon causes the bombardment of the structure by alpha particles, which gradually disrupt the structure. This disruption is reflected in the optical properties of the zircon and the adjacent parts of the surrounding minerals, where zircons loose their transparency, and birefringence decreases. Poldervaart (1956) suggested that malacon may be also formed as the result of hydrothermal alteration. In this case, the zircons are non-radioactive. The mineral is composed essentially of $\mathrm{ZrO}_{2}$ and $\mathrm{SiO}_{2}$ with traces of $\mathrm{ThO}_{2}, \mathrm{Hf}_{2} \mathrm{O}_{3}, \mathrm{Fe}_{2} \mathrm{O}_{3}, \mathrm{CaO}, \mathrm{UO}_{2}$ and $\mathrm{Al}_{2} \mathrm{O}_{3}$ (Fig. 12). The average $\mathrm{Zr} / \mathrm{Hf}$ ratio is 21.32 reflecting the acidic origin of the magma from which these zircon were originated. Noteworthy, many of thorite and zircon grains in the studied granitic pegmatites show solid solution range, where $\mathrm{Zr}$ rich thorites and Th-rich zircons are present.

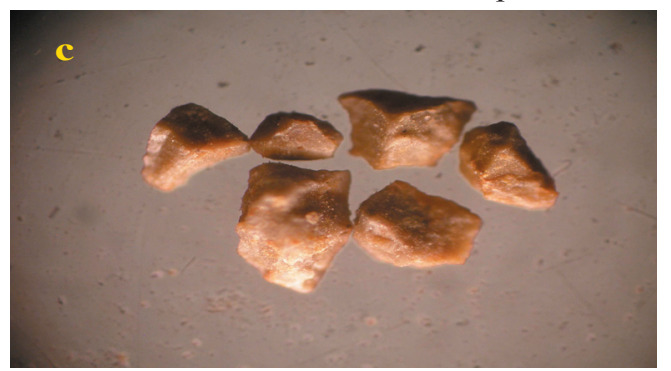

Fig. 11: Photomicrographs of the considered radioactive minerals; c) zircon

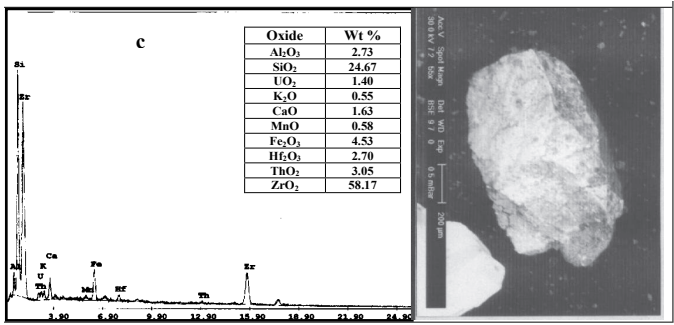

Fig. 12: EDX analyses and backscattered ESEM image of [c] malacon zircon grain
Förster (2006) demonstrated that the local disequilibrium processes such as supersaturation may have aided in the precipitation of the metastable thorian zircon and zirconian thorite. A sample of zircon was heated to $1000^{\circ} \mathrm{C}$ for three hours and analyzed using X-ray diffraction technique. The obtained data are listed in Table (2), which indicate that the presence of thorite diffraction peaks in addition to that of zircon reflecting the intermediate solid solution of zircon and thorite. According to Rozendaal and Philander (2000):

- clear zircons contain: low levels of Fe, $\mathrm{U}$ and $\mathrm{Th}$

- pink zircons: increased levels of rare earths (RE), U and Th

- yellow zircons: highly increased levels of RE, U, Th and increased levels of Fe, $\mathrm{Al}, \mathrm{P}$ and $\mathrm{Ca}$

- metamictic zircons: very highly increased levels of RE, U (up to the \% range), $\mathrm{Fe}$ and $\mathrm{Y}$.

Betafite [( Ca, U) 2( $\mathrm{Ti}, \mathrm{Nb}, \mathrm{Ta}) 2 \mathrm{O6}(\mathrm{OH})]$ Pyrochlore group of minerals are classified into three subgroups on the basis of the B-site composition (Hogarth, 1977): pyrochlore is the $\mathrm{Nb}$-dominant member, microlite is the Ta-dominant member and betafite has $2 \mathrm{Ti}>(\mathrm{Nb}+\mathrm{Ta})$. Hogarth (1961) demonstrated that a compositional series exists between pyrochlore and betafite, thus firmly establishing betafite as a member of the pyrochlore group. Betafite is rarely observed in the studied granitic pegmatites of the study area and was detected by ESEM technique. It occurs as anhedral fragmental grains of black color and vitreous luster. It is characterized by its concoidal fractures and yellow superficial alteration of some betafite grains (Fig. 13). ESEM analyses of some betafite grains reveal that they consist mainly of $\mathrm{Nb}, \mathrm{U}$, Ti with appreciable amount of Fe, Si, Y, Ta, Mn, Th and Al (Fig. 14). 


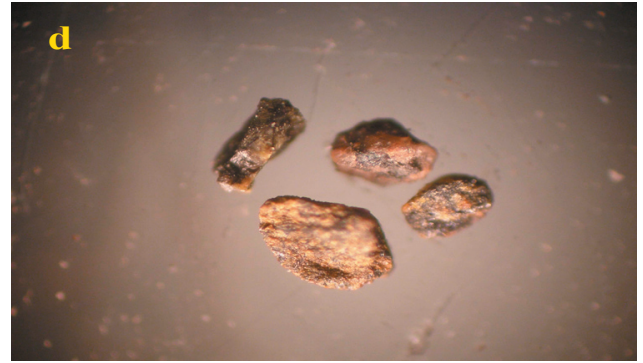

Fig. 13: Photomicrographs of the considered radioactive minerals; d) betafite

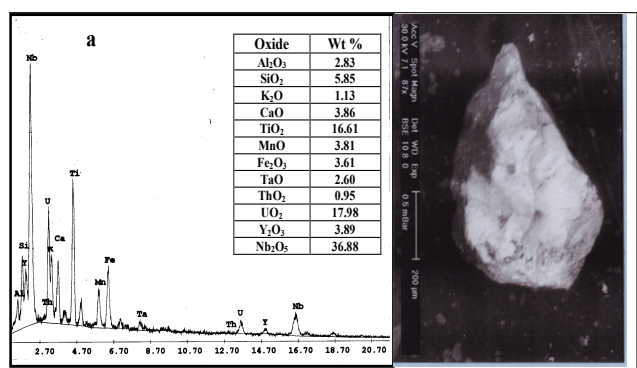

Fig. 14: EDX analyses and backscattered ESEM image of [a] betafite

Fluorite [CaF $]$ ]: The hig alkalinity in the magmatic melts and mineralizing solutions play an important role due to the presence of fluorine which caused full separation of the LREE and hence preferential accumulation of the HREE in the fluorite (Bulnayev and Kaperskaya, 1990). Fluorite in the studied pegmatites exhibit wide range of colors from colorless, pale blue to dark violet with vitreous and resinous luster (Fig.15). Allen (1952) concluded that the coloration of fluorite can be attributed to the action REE during the differentiation of the magma, presence of manganese or distortion in the crystal structure. EDX mineral analysis of the mineral reveals that it is composed essentially of $\mathrm{Ca}$ and $\mathrm{F}$ with the presence of trace amounts $(<3.5 \%)$ of $\mathrm{Si}, \mathrm{Al}, \mathrm{Mn}$ and $\mathrm{Fe}$. Some fluorite mineral grains contain inclusions from ishikawaite and thorite (Fig. 16). Table (3) gives the X-ray diffraction data of the picked fluorite grains from the studied pegmatites.

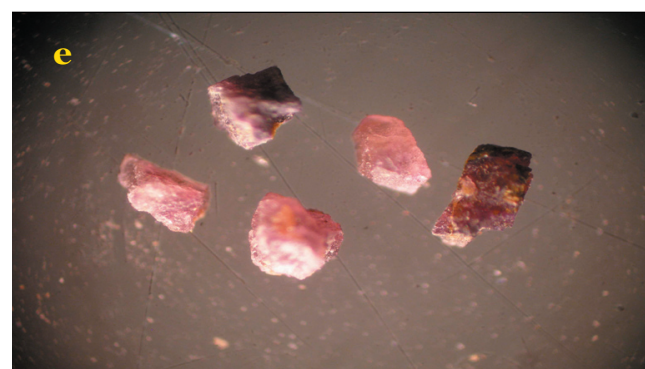

Fig. 15: Photomicrographs of the considered radioactive minerals; e) fluorite

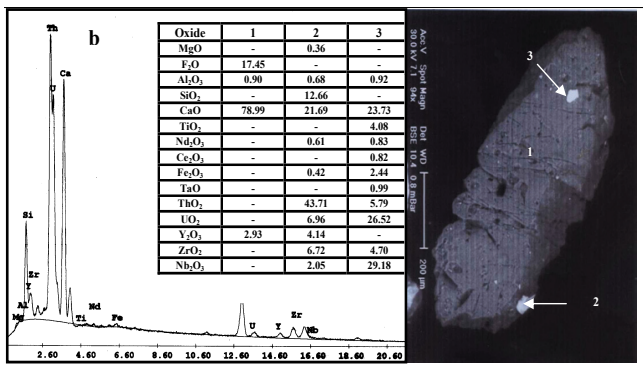

Fig. 16: EDX analyses and backscattered ESEM image of [b] fluorite grain with inclusions of thorite (2) and ishikawaite (3)

Table (3): X-ray diffraction data of the studied fluorite, zircon and anatase.

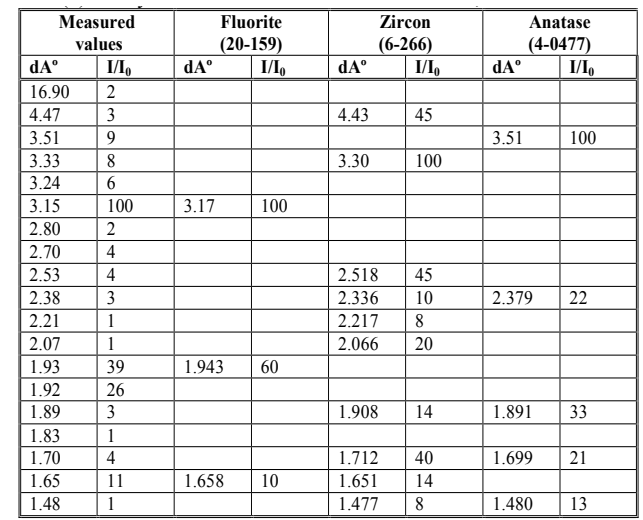

Anatase [TiO ]: Most of anatase grains in the studied pegmatites occur as anhedral to subhedral opaque yellow to yellowish brown grains with resinous luster (Fig. 17). It consists entirely of $\mathrm{TiO}_{2}$ with appreciable amount of $\mathrm{Fe}_{2} \mathrm{O}_{3}$ and traces of $\mathrm{CaO}$ and $\mathrm{K}_{2} \mathrm{O}$ (Fig. 18). 


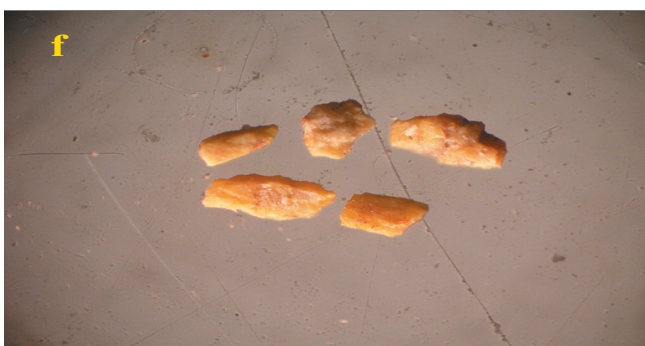

Fig. 17: Photomicrographs of the considered radioactive minerals; f) anatase

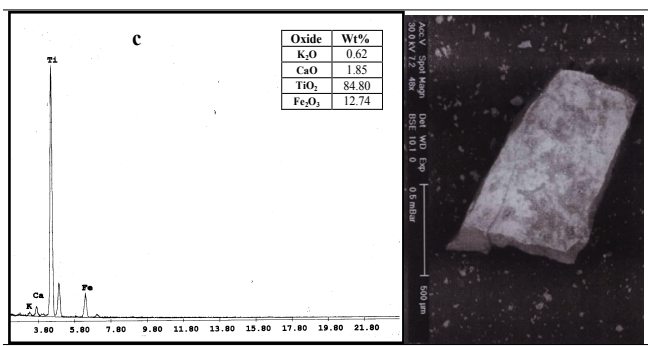

Fig. 18: EDX analyses and backscattered ESEM image of $[\mathrm{c}]$ anatase

In addition to the previously mentioned minerals, there are appreciable quantities of magnetite and hematite, which exist due to the hematitization of some parts of pegmatites in the studied area.

\section{CONCLUSIONS}

The Neoproterozoic rock units exposed at the studied area comprise gneisses and migmatites, old granitoids and monzogranites. The pegmatitic bodies are hosted mainly in monzogranites. The pegmatite bodies are mainly of the simple unzoned type and most of the radioactive mineralizations are related to the accumulations of micas. The studied pegmatites can be considered as uraniferous pegmatites being contain very high values of radioelements $\mathrm{U}$ and $\mathrm{Th}$ and formed in U-positive radioactive disequilibrium. The distribution of radioelements can be attributed to the magmatic processes as well as hydrothermal alteration. The important radioactive minerals are ishikawaite, thorite, thorianite, zircon, be- tafite and fluorite. In most ishikawaite mineral grains $T h$ is prevailing $U$, so the mineral ishikawaite can be classified to ishikawaite-Th and ishikawaite-U. Exsolution intergrowths of thorianite and ishikawaite-U occur in ishikawaite-Th grains.

\section{REFERENCES}

Abdel Warith, A., 2001. Morphological and geochemical characteristics of zircon as a guide to uranium origin in El Missikat and El Erediya plutons, Central Eastern Desert, Egypt. J. Fac. Educ., 26, 141-156.

Abu El-Enen, M.M., 2008. Geochemistry and metamorphism of the Pan-African back-arc Malhaq volcano-sedimentary Neoproterozoic association, Wadi Kid area, SE Sinai, Egypt. J. Afri. Earth Sci., 51,189-206.

Allen, R.D.,1952. Variation in chemical and physical properties of fluorite. Am. Mineral., 37, 910-930.

Bulnayev, K.B. and Kaperskaya, Y.N., 1990. Trends in the rare earth distribution in fluorite from various type deposits in Transbaykalia. Translated from Geokhimya,12, 1742-1755.

Charbonneau. B. W.,1982. Radiometric study of three radioactive granites in the Canadian Shield: Elliot Lake, Ontario; Fort Smith, Fury and Hecla, NWT. In: Maurice, Y.T. (Ed.),Uranium in granites .Geol. Surv. Canada, 88-23,91-99.

Dardier, A.M., 1999. Morphology and geochemistry of zircon associated with uranium mineralization in Gattar granitic pluton, north Eastern Desert, Egypt. Egypt. Mineral., 11, 91-104.

Darnely, A.G., 1982. Hot granites: some general remarks. In: Maurice, Y.T. (Ed.), uranium in granites. Geol. Surv. Canada, Paper 81-23, 1-10.

El Aassy, I. E, El Sayed, A.A., Sherief, H.Y. and Ahmed, F.Y., 1999. Secondary uranium mineralization in Wadi Ghazala, southeastern Sinai, Egypt. Seminar on Nuclear Raws and their technology, 253-269. 
El Baily, M.Z. and Streck, M.J., 2009. Late Neoproterozoic alkaline magmatism in the Arabian-Nubian Shield: The postcollisional A-type granite in Sahara Um Adawi pluton, Sinai, Egypt. Arab. J. Geo. Sci., 151-174.

El Feky, M.G., El Mowafy A.A. and Abdel Warith A., 2011. Mineralogy, geochemistry, radioactivity and environmental impacts of Gabal Marwa granites, Southeastern Sinai, Egypt. Chin. J. Geoch. ,30, 175-186.

El.Mansi, M.M., Dardier, A.M. and Abdel Ghani, I.M.,2004. Crystal habit and chemistry of zircon as a guide for uranium redistribution in Gabal Ria El Garrah area, Eastern Desert, Egypt. Delta J. Sci., 28, 19-30.

El Metwally, A.A., 1993. Microgranular enclaves in the Pan-African I-type granites from Sinai Massif: Petrology, mineralogy and geochemistry. J. Afr. Earth Sci., 17, 95-110.

El Mowafy, A.A., 1994. Geology and radioactivity of Southwestern Nuweiba area, Sinai, Egypt. M. Sc. Thesis, Fac. Sci., Mansoura Univ., Egypt, 203p.

El Mowafy, A.A., 2003. Younger granite and microgranite dyke rocks of G. Um Ikhsi, Southeastern Sinai, Egypt: Geology, petrogenesis and radioactivity. Egypt. J. Geol., 47/2, 731-749.

El Nahas, H.A., 2006. Distribution of nuclear minerals in G. Hamra environs, Southern Sinai, Egypt. Ph. D. Thesis, Fac. Sci. Minufiya Univ. Egypt., 159p.

El Sayed, A.A., 1993. Geology and radioactivity of West Dahab area, Southeastern Sinai, Egypt. M. Sc. Thesis, Fac. Sci., Mansoura Univ., Egypt, 174p.

Ford, K.L., 1982. Uraniferous pegmatites of the Sharbot lake area, Ontario: In Maurice, Y.T. (Ed.),Uranium in granites. Geol. Surv. Canada, 81-23,125-138.

Förster, H. -J., 2006. Composition and origin of intermediate solid solutions in the system thoritexenotime-zircon-coffinite. Lithos, 88, Issues 1-4, $35-55$.

Hamd, M.S., 1995.: Geology of the basement rocks of the area around Ein Furtaga, West Nuweiba, South Sinai, Egypt. M.Sc. Thesis, Cairo Univ., 217p.
Hanson, S.L., Simmons, W.B., Flaster, A.U. Foord, E.E and Lichte, F.E., 1999. Proposed nomenclature for samarskite-group minerals: new data ishikawaite and calciosamarskite. Min. Mag., 63, 27-36.

Hogarth, D.D., 1961. A study of pyrochlore and betafite. Canadian Mineral.,6, 610-633.

Hogarth, D.D., 1977. Classification and nomenclature of the pyrochlore group. Am. Mineral., 62, 403410.

Moghazy, A.M., Anderson, T., Oweis, G., and Boseily, A.M., 1998. Geochemical and $\mathrm{Sr}-\mathrm{Nd}-\mathrm{Pb}$ isotopic data bearing on the origin of the Pan-African granitoids in the Kid area, Southeast Sinai, Egypt. J. Geol. Soc., 155, Part 4, 697-710.

Moharam, A.F., 2004. Uranium distribution in the Um Samra-Um Baraka granitic plutons and associated pegmatites, Central Eastern Desert, Egypt. Pro. 7th Arab Conf. on the Peaceful Uses of Atomic Energy, II, 311-325.

Moharam, A.F., 2006. Petrology and uranium distribution in the Um Samra - Um Bakra granitic plutons, central Eastern Desert, Egypt. J. Fac. Educ., 31, 67-90.

Poldervaart, A., 1956. Zircons: 2) Igneous Rock. Am. J. Sci.,253, 433-461.

Rozendaal, A. and Philander, C., 2000. Mineralogy of heavy mineral placers along the west coast of South Africa. In: Rammlmair, D., Mederer, J., Oberthur, T., Heimann, R.B. and Pentinghaus, H., (Eds), Applied mineralogy in research, economy, technology, ecology and culture. Proc. 6th Intern. Congr. Applied Mineralogy, ICAM . Göttingen, Germany, 417-420, Rotterdam (Balkema).

Salterly, J., 1957, Radioactive mineral resources in the Bancroft Area. Ontario Dept. Mines Ann. Rept., 56, 65, Pt. 6, 181p.

Van Schmus, W.R., 1995. Natural radioactivity of the Crust and Mantle. In: Ahrens, T.J. (Ed.), Global Earth Physics: A Handbook of Physical Constants. Am. Geophy. Union, AGU Reference Shelf 1, 283-291. 


$$
\text { هشام النحاس }
$$

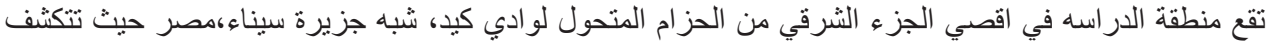

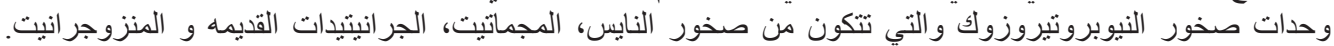

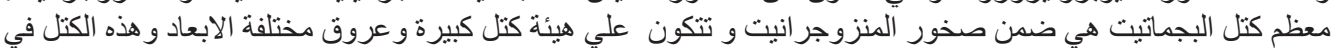

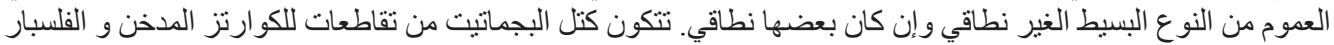

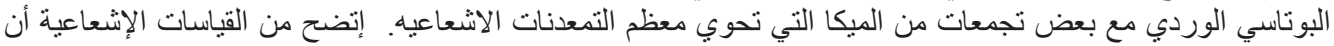

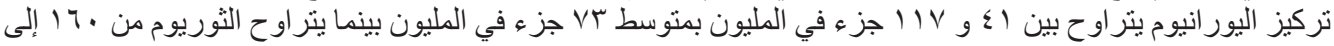

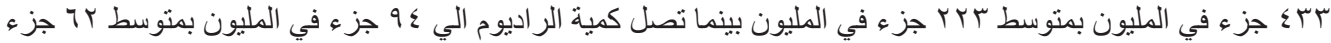

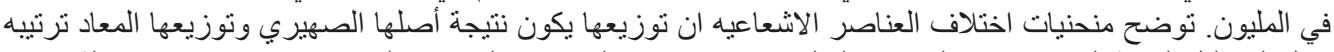

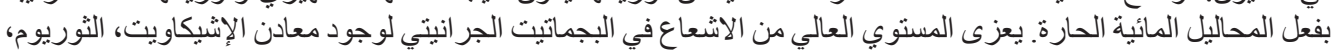

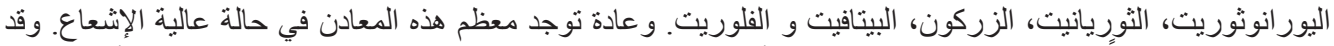

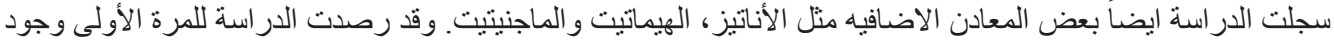
معدن الإشيكاويت الثوريومي الذي يسود به الثوريوم عن اليورانيوم وهذا المعدن هو نمو متشابك بين معدني الإشيكاويت الإنيت 